\title{
Antiviral Activity of Adamantane-Pyrazole Derivatives Against Foot and Mouth Disease Virus Infection in vivo and in vitro With Molecular Docking Study
}

\author{
Mohammed M. S. Wassel ${ }^{1}$; Wael M. Gamal El-Din ${ }^{{ }^{*}}$; Ahmed Ragab ${ }^{2}$; Gameel A. M. Elhag Ali \\ and Yousry A. Ammar ${ }^{2}$ \\ ${ }^{1}$ Department of Foot and Mouth Disease, Veterinary Serum and Vaccine Research Institute (VSVRI), \\ Agricultural Research Center (ARC), Abbasia, Cairo, Egypt. \\ ${ }^{2}$ Chemistry Department, Faculty of Science, Al-Azhar University, Nasr City, 11884, Cairo, Egypt. \\ *Corresponding Author, Wael M. Gamal El-Din, E-mail: waelmossad@gmail.com
}

\begin{abstract}
Foot-and-mouth disease (FMD) vaccine does not afford early effective protection until adaptive immune protection caused by the vaccination occurs. Therefore, an alternative prophylactic application of antiviral agents for inhibition of the FMD virus is needed, and this is the scope of this study. In this study, we tested nine adamantane-pyrazole derivatives that could exhibit antiviral activity against FMDV infection either in vitro through baby hamster kidney cells (BHK-21 cells) infected with FMD virus serotypes $\mathrm{O}$ pan Asia. Cytotoxicity Concentration $50\left(\mathrm{CC}_{50}\right)$ activity of pyrazole derivatives $(1,2,3,4,5 \mathrm{a}, \mathrm{b}, 6 \mathrm{a}-\mathrm{c})$ were detected on BHK-21 cells and ranged between 500 to $3000 \mu \mathrm{g} / \mathrm{ml}$. Inhibitory Concentration 50 $\left(\mathrm{IC}_{50}\right)$ on BHK-21 was achieved only for the most promising three derivatives $6 a-c$ and exhibited an antiviral activity with a therapeutic index of 30, and that was reflected on the antiviral activity response in baby mice with different concentrations where a concentration of $50 \mu \mathrm{g} / \mathrm{ml}$ for pyrazole derivatives $6 \mathrm{a}$ and $6 \mathrm{c}$ compounds and $40 \mu \mathrm{g} / \mathrm{ml}$ for bis-tolyl pyrazole $6 \mathrm{~b}$ that achieve $100 \%$ protection and this results was as effective as $50 \mu \mathrm{g} / \mathrm{ml}$ of amantadine. Specifically, diaryl pyrazole derivatives $6 \mathrm{a}-\mathrm{c}$ that protected for six days following FMDV challenge. These results suggested that pyrazole derivatives 6 a-c could be used as an effective antiviral agent against FMD virus infection. Molecular docking simulation of the target compounds 6a-c had good binding energy and the tested compounds recommended being an excellent 3C protease inhibitor compared to Amantadine and Ribavirin. These findings may explain the antiviral activity of the target compounds.
\end{abstract}

Original Article:

DOI:https://dx.doi.org/10.21608/ja vs.2020.118001

Received : 07 Aug., 2020.

Accepted:15 Sept., 2020.

Published in October, 2020.

This is an open access article under the term of the Creative Commons Attribution 4.0 (CCBY) International License. To view a copy of this license, visit:

http://creativecommons.org/licenses/by/4.0/

Keywords: Adamantane derivatives, Amantadine, Antiviral, BHK- J. Appl. Vet. Sci., 5(4): 37 - 46. 21 cells, FMDV.

\section{INTRODUCTION}

Foot-and-mouth disease (FMD) is one of the most economically and publicly devastating diseases that affects cloven-hoof animals including cattle, sheep, swine and goats (Grubman and Baxt, 2004). The main clinical signs of this disease include fever, inappetance, lameness, and the appearance of vesicular lesions in the mouth, snout, teats, and feet (S. Alexandersen and Zhang,2003). The virus spreads by direct contact with infected animals, and indirect contact via contaminated animal products, animate and inanimate objects and by atmospheric dispersal (Ibrahim et al., 2017).The FMDV is belongs to the genus Aphthovirus within the family Picornaviridae and is a small, non-enveloped virus, which has a single-stranded positive- sense RNA genome. The virus consists of seven distinct serotypes $\mathrm{O}, \mathrm{A}, \mathrm{C}$, Asia1 and Southern African Territories (SAT) 1-3 and as multiple subtypes due to the high mutation rate of the virus (Moraes and Koster, et al.,2007). The viral capsid consists of 60 copies of four structural proteins (VP1, VP2, VP3, and VP4).

Although FMD vaccines have been accessible since the early 1900 s and new novel vaccines are being continuously established, including inactivated whole virus vaccines, new inactivated whole virus marker 
vaccines and subunit vaccine. These vaccines do not offer early complete clinical protection up to seven days' post-vaccination and also, they offer little or no cross-protection against various serotypes and subtypes of FMDV. Thus there is a necessity for developing an effective and safe alternative antiviral approach against FMDV (Diaz-San., 2017). Therefore, finding an active antiviral agent against FMDV infection is necessary to control the incidence of foot and mouth disease virus infection and thus saving some adverse economic impact that may occur upon infection.

Adamantane derivatives have found numerous applications in different fields of chemistry, but their use in catalysis (Agnew-Francisa and Williams.,2016). Moreover, medicinal chemistry ( Kazimierczuk et al.,2001) and (Kitagawa et al.,1997) which has been especially fruitful. With a low molecular weight and highly symmetric structure, adamantine fragments provide a domain with critical lipophilicity (with a molecular diameter of $6.36 \AA$ (N. Moreldesrosiers and Morel., 1979). When inserted in the structure of known pharmacophores, improving pharmacokinetic profiles of the modified drugs. ( Igumnova et al., 1988) and (Augeri et al., 2012) Simple amino adamantane (amantadine) have occupied a reliable place in the pharmaceutical market, showing their efficiency for the treatment of viral diseases as influenza A, herpes, hepatitis C and HIV. (AgnewFrancisa and Williams.,2016).

However, the release of virions from cells infected with FMDV was inhibited by amantadine, a viroporin inhibitor such as amantadine that closes transmembrane pores in host cells via oligomerization (AO et al. , 2015)., The virus titer decreased as the amantadine concentration increased, which suggests that amantadine inhibited the release of the virus from the cells and that viroporins may be involved in this process as shown in (Fig. 1). In this study, we examined the antiviral efficacy of nine adamantane pyrazole derivatives in vitro and in vivo in comparison with amantadine against foot and mouth disease virus

\section{MATERIALS AND METHODS}

\section{Ethical approval}

The experiment was carried out according to the protocol of the Institutional Animal Ethics Committee, and the authors had the permission of the $\mathrm{Lab}$ animal isolator.

\section{FMD Virus serotype}

Local Foot and Mouth disease virus serotypes O pan Asia propagated in Baby Hamster Kidney (BHK-21) cell line monolayer was supplied by the Department of Foot and Mouth Disease Research, Veterinary Serum and Vaccine Research Institute (VSVRI), Abbasia, Cairo, Egypt. The titer of the serotype was expressed as $\log { }_{10} \mathrm{TCID}_{50} / \mathrm{ml}$ as calculated by (Reed and Muench, 1938). Virus stocks were prepared as aliquots of culture medium from BHK-21 cells infected and stored at $-70{ }^{\circ} \mathrm{C}$. Working stocks were prepared and titration of the virus by serial dilution in a culture medium.

\section{Cell culture}

Baby Hamster kidney cell line (BHK-21) was supplied by VSVRI using Eagle's medium supplemented with $8-10 \%$ bovine serum, $60 \mathrm{~g} / \mathrm{ml}$ Penicillin G and $100 \mathrm{~g} / \mathrm{ml}$ Streptomycin sulfate maintain at $37{ }^{\circ} \mathrm{C}$ (Soudy., 2019). All medium components were obtained from Sigma Chemical Co.; (Xuan et al., 2011).

\section{Suckling baby mice}

Suckling Swiss baby mice, two to four days old, (Charles River Strain, USA) were supplied by the Laboratory Animal Department of VSVRI, Abbasia, Cairo, Egypt.

\section{Chemistry of antiviral agent}

Our previous study reported the design and synthesis of novel series adamantane-pyrazole (Wassel et al., 2020) and differed in substituents in three carbon of pyrazole, as showed in table1. The pyrazole derivative relationship revealed that pyrazole derivative 1 contains thiomethyl group and enaminonitrile, while compound 2 involves enaminonitrile only and pyrazole derivative 3 involved acetamide derivatives beside the cyano group. Pyrazole derivative 4 showed three subsistent as phenyl, tolyl, and methylene Amantadine carbohydrazide derivative. Similarly, diamino-pyrazole derivatives $5 \mathrm{a}, \mathrm{b}$ displayed the difference in an azo-aryl group (phenyl 5a, and p-methoxy phenyl 5b). Finally, di-aryl pyrazoles 6a-c demonstrated two aryl groups at positions three and five to pyrazole nucleus.

The compound samples were prepared for assay by dissolving $0.01 \%$ of DMSO and diluting aliquots into sterile culture media at $0.1 \mathrm{gm} / 10 \mathrm{ml}$ stock solution of different compounds which was filtered through a $0.2 \mu$ cellulose acetate membrane (Millipore). The different concentrations of tested compounds (1, 2, 3, 4, 5a, b and 6a-c) used as antiviral were 20 to $4000 \mu \mathrm{g} / \mathrm{ml}$ in triplicates in the wells of microtiter plates.

\section{Determination of Cytotoxic Activity}

Cytotoxicity of different compounds against BHK-21 cells was analyzed based on cellular and morphological changes in a monolayer of cells under a light microscope and viable cell count by trypan blue dye exclusion method ( Strober ., 2011). In brief, different concentrations of the compounds were prepared in Glasgow minimum essential medium (GMEM). BHK-21 cells $\left(1 \times 10^{4}\right.$ cells/well $)$ were propagated in 96 well cell culture plates in the presence of diluted compounds (starting from 20 to $4000 \mu \mathrm{g} / \mathrm{ml}$ ) by co-cultivation method and incubated at $37{ }^{\circ} \mathrm{C}$ for 48 hrs with appropriate cell control. Cells were observed 
after 24 hrs interval for visible morphological changes under an inverted microscope and the treated wells were compared with the untreated wells. The total viable cell and viable cell (\%) was calculated in comparison to cell control (untreated group) using hemocytometer at a different time interval. The highest concentration of the drugs evincing no cellular or morphological alterations and viable cell count C 50\% as assessed by trypan blue staining was considered as its respective $\mathrm{CC}_{50}$. Concentrations of drugs exhibiting toxicity to cells were not considered and the concentrations below $\mathrm{CC}_{50}$ were employed to study the antiviral activity.

\section{Antiviral assays}

\section{Virus yield assay in tissue culture}

BHK cells were incubated overnight with dilutions of tested compounds containing supernatants. Supernatants were removed and cells were washed with minimal essential medium (MEM; Gibco BRL/Invitrogen). Cells were infected at a MOI of 1 with FMDV O Pan Asia for $1 \mathrm{hr}$, and the unabsorbed virus was inactivated by washing the cells with 150 $\mathrm{mM} \mathrm{NaCl}, 20 \mathrm{mM}$ morpholine ethane sulfonic acid (MES) (pH 6). MEM was added, and incubation continued for $24 \mathrm{hrs}$. The virus was released by one freeze-thaw cycle. As a control, infected cells were frozen and thawed at $1 \mathrm{hr}$ post infection (p.i). Virus yields were determined by virus titration assay on BHK-21 cells and expressed by subtracting the titers of the virus which being expressed as $\log _{10} \mathrm{TCID}_{50}$ in cells infected for $1 \mathrm{hr}$ from then $24 \mathrm{hrs}$ titers. The reduction ( $n$-fold) was calculated by dividing the virus titer into untreated infected cells by the virus titer in treated infected cells. The results are expressed by means from three repetitions (Mauro et al., 2007).

\section{Antiviral reagent injection, viral challenge, and monitoring in suckling mice}

Laboratory Animal Department supplied one hundred and seventy specific-pathogenic free suckling mice, 3 to 4 days old (Charles River Strain, USA).; VSVRI, Abbasia, Cairo, Egypt and were used further to investigate the antiviral activity of adamantanepyrazole derivatives in vivo. The FMDV dose was determined through 10 -folds serial dilutions of the virus. The $50 \%$ lethal dose $\left(\mathrm{LD}_{50}\right)$ of FMDV serotype O Pan Asia was estimated by the Reed-Muench method. Suckling mice were inoculated by intraperitoneal injection with a different safe concentrations of the di-aryl pyrazole derivatives 6a-c that ranged between $100,50,40,30,20 \mu \mathrm{g} / \mathrm{ml}$ while other compounds were not included as there is no antiviral activity evidence on tissue culture. Mice were treated with PBS containing 10\% DMSO and 5\% Tween- 80 in the same volume as controls. Two hours following adamantane-pyrazole derivatives $(6 a, 6 b$ and 6c) injection, the suckling mice were challenged with
$100 \mathrm{LD}_{50}$ FMDV serotypes (O) in a volume of $100 \mu \mathrm{l}$ by intraperitoneal injection. The animals were monitored for five days. After $48 \mathrm{hrs}$ post-inoculation, the positive results showed spastic muscular paralysis of hindquarters leading to death due to activity of FMD virus but the action of different safe concentration of compounds were proved in life mice expressed as a percentage of several survivals.

\section{In silico molecular docking simulation}

The molecular docking modeling studies were carried out by the help of MOE software (Molecular Operating Environment 10.2008 provided with chemical computing group, Canada). The X-ray crystallographic structure of the $3 \mathrm{C}$ protease (PDB: $5 \mathrm{MH} 2$ ) was retractive from protein data bank that isolated from Foot-and-mouth disease virus - type SAT 2 and released at 2016-03-02 with resolution: $3.20 \AA$ (https://www.rcsb.org/structure/5HM2, last accessed 5 Aug. 2020).

The isolated 3C proteinase consists of five chains and each chain consisted of 209 amino acids, our study used only one chain. Added hydrogen atoms prepared the protein structures for the docking to the complex structure and electric charge by Protonate 3D (default settings). The hydrogen atoms were optimized by MMFF94x force field (the heavy atoms were fixed during the optimization and the dummy atoms were disposed of the docking site by Site Finder (default settings). Triangle Matcher placement method and London $\mathrm{dG}$ scoring function with retaining 50 times were used for docking. The pyrazole derivatives 6a-c as well as the standard drugs Amantadine and Ribavirin were drawn in chem-draw 14.0 and exported to MOE where protonated 3D, minimized energy and render hydrogen was achieved and finally docked inside the active site of the protein.

\section{RESULTS}

Before checking the antiviral activity of the compounds through observation of the cytopathic effect of FMDV on BHK-21, the compounds were screened for their cytotoxicity to BHK-21 cells which are characterized by a change in cell morphology like rounding, increased brightness, and detachment of the cells from the surface (Sarkar et al., 2019). The observed cytotoxic changes in the cells were directly proportional to the concentration of the compound starting from 20 to $4000 \mu \mathrm{g} / \mathrm{ml}$. The results as shown in Table (1) revealed that the cytotoxicity concentration $50\left(\mathrm{CC}_{50}\right)$ on BHK-21 cells of compound $(1,2$ and 4$)$ was $1000 \mu \mathrm{g} / \mathrm{ml}$, compound (3) was $500 \mu \mathrm{g} / \mathrm{ml}$, compound $5 \mathrm{a}$ and $5 \mathrm{~b}$ was $2000 \mu \mathrm{g} / \mathrm{ml}$ and compound (6a , $6 \mathrm{~b}$ and $6 \mathrm{c}$ ) was $3000 \mu \mathrm{g} / \mathrm{ml}$.There is a variety of cytotoxic concentration 50 between the derivatives of adamantane-pyrazole . 
Table 1: The effect of different concentrations of adamantane pyrazole derivatives on healthy BHK cells. $* \mathrm{CC}_{50}$ : BHK cytotoxic concentration fifty.

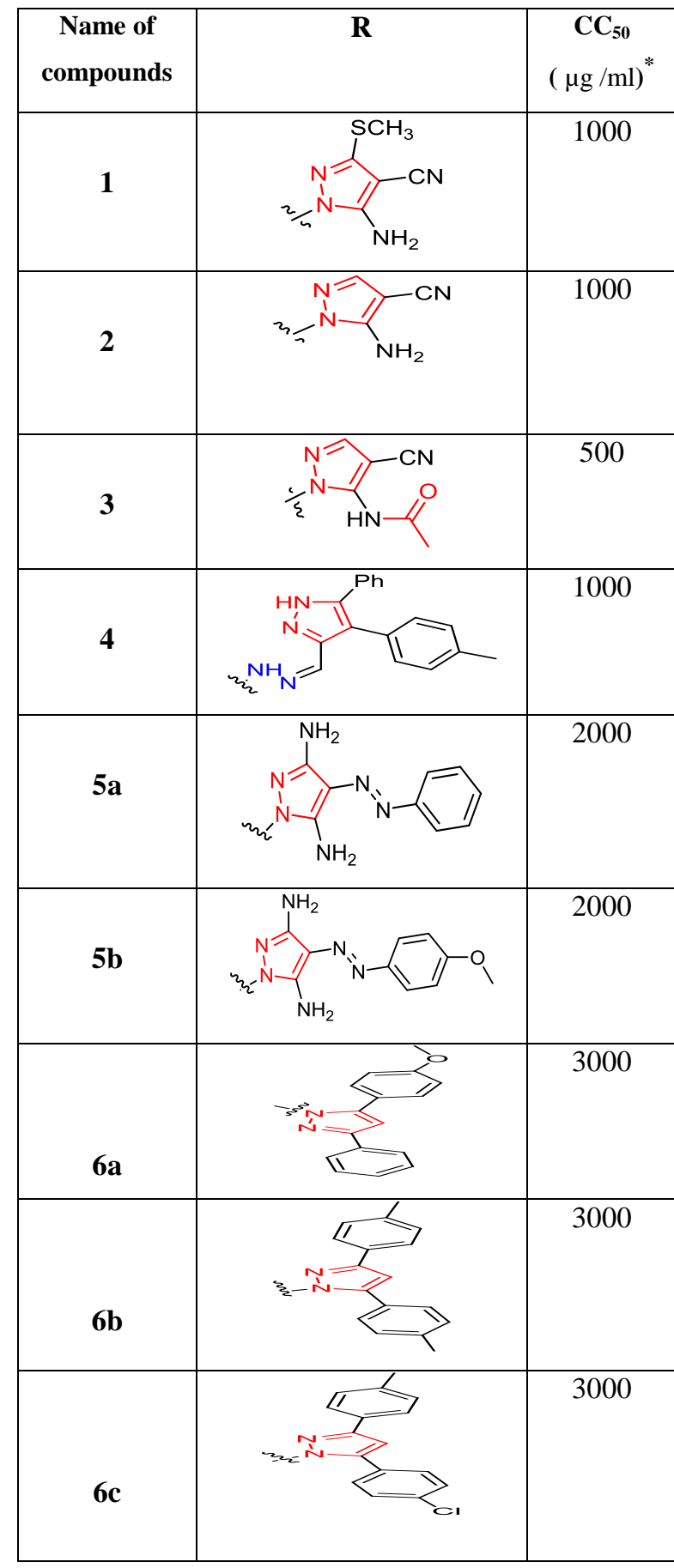

The results of Table 2, showed that the pyrazole derivatives $1,2,3,4,5 \mathrm{a}$ and $5 \mathrm{~b}$ did not achieve a comparable degree of inhibition or mean viral titer fold reduction subsequently, and these compounds did not show any antiviral activity on BHK-21. While pyrazole with di-aryl group 6a-c as shown in Table 3 showed a marked antiviral activity on BHK-21 cells as the mean virus titer reduction was achieved from $10^{8.5}$ expressed by $\log _{10} \mathrm{TCID}_{50}$ on BHK-21 till reaching its minimum mean virus titer of $10^{1.25} \log _{10}$. Inhibitory concentration $50\left(\mathrm{IC}_{50}\right)$ was achieved at $100 \mu \mathrm{g} / \mathrm{ml}$ for the pyrazole derivatives $6 \mathrm{a}-$ c. Where in case of compound 6a give mean virus titer 4.2 with 2-folds reduction in virus titer, also compound $6 \mathrm{~b}$ give mean virus titer 3.9 with 2.1 -folds reduction in virus titer and compound $6 \mathrm{c}$ give mean virus titer 4.2 and with 2.4 folds reduction in virus titer. The therapeutic index (TI) was calculated from previous results for diaryl pyrazole derivatives $6 a-c$ and displayed 30.

Table 2: Antiviral activity of adamantane pyrazole derivatives no. 1, 2, 3, 4,5a and 5b in BHK cell

\begin{tabular}{|c|c|c|c|}
\hline $\begin{array}{c}\text { Name of } \\
\text { compounds }\end{array}$ & $\begin{array}{c}\text { The } \\
\text { concentration } \\
\text { of compound }^{\text {a }}\end{array}$ & $\begin{array}{c}\text { Mean } \\
\text { virus } \\
\text { titer }^{\mathbf{b}, \mathbf{d}}\end{array}$ & $\begin{array}{c}\text { Fold } \\
\text { reduction }^{\mathrm{c}}\end{array}$ \\
\hline- & - & 8.5 & - \\
\hline \multirow{6}{*}{1} & 1000 & 8.3 & 1 \\
\hline & 500 & 8.5 & 0 \\
\hline & 200 & 8.2 & 1 \\
\hline & 100 & 8.5 & 0 \\
\hline & 50 & 8.4 & 1 \\
\hline & 20 & 8.5 & 0 \\
\hline \multirow{6}{*}{2} & 1000 & 8.4 & 1 \\
\hline & 500 & 8.4 & 1 \\
\hline & 200 & 8.5 & 0 \\
\hline & 100 & 8.2 & 1 \\
\hline & 50 & 8.3 & 1 \\
\hline & 20 & 8.4 & 1 \\
\hline \multirow{6}{*}{3} & 500 & 8.4 & 1 \\
\hline & 200 & 8.3 & 1 \\
\hline & 100 & 8.3 & 1 \\
\hline & 50 & 8.5 & 0 \\
\hline & 10 & 8.5 & 0 \\
\hline & 2 & 8.5 & 0 \\
\hline \multirow{6}{*}{4} & 1000 & 8.4 & 1 \\
\hline & 500 & 8.4 & 1 \\
\hline & 200 & 8.2 & 1 \\
\hline & 100 & 8.4 & 1 \\
\hline & 50 & 8.3 & 1 \\
\hline & 20 & 8.5 & 0 \\
\hline \multirow{6}{*}{$5 a$} & 2000 & 8.5 & 0 \\
\hline & 1000 & 8.4 & 1 \\
\hline & 500 & 8.4 & 1 \\
\hline & 100 & 8.5 & 0 \\
\hline & 50 & 8.4 & 1 \\
\hline & 20 & 8.5 & 0 \\
\hline \multirow{6}{*}{$5 b$} & 2000 & 8.5 & 0 \\
\hline & 1000 & 8.5 & 0 \\
\hline & 500 & 8.4 & 1 \\
\hline & 100 & 8.4 & 1 \\
\hline & 50 & 8.4 & 1 \\
\hline & 20 & 8.5 & 0 \\
\hline
\end{tabular}

${ }^{\mathbf{a}}(\mu \mathrm{g} / \mathrm{ml})-{ }^{\mathbf{b}}$ Expressed by $\log _{10}$ TCID $_{50}-{ }^{\mathbf{c}}$ The reduction $(n-$ fold) was calculated by dividing the virus titer into untreated cells by the virus titer in treated cells.- ${ }^{d}$ Results are means from three repetitions 
Table 3: Antiviral activity of adamantane pyrazole derivatives no. $6 a, 6 b$ and $6 \mathrm{c}$ in BHK cell

\begin{tabular}{|c|c|c|c|}
\hline $\begin{array}{c}\text { Name of } \\
\text { compounds }\end{array}$ & $\begin{array}{c}\text { Concentration } \\
\text { of compound }^{\mathrm{a}}\end{array}$ & $\begin{array}{c}\text { Mean virus } \\
\text { titer }^{\mathrm{b}, \mathrm{d}}\end{array}$ & $\begin{array}{c}\text { Fold } \\
\text { reduction }\end{array}$ \\
\hline- & - & 8.5 & - \\
\hline \multirow{4}{*}{ 6a } & 3000 & 1.8 & 4.7 \\
\cline { 2 - 4 } & 1000 & 2.5 & 3.4 \\
\cline { 2 - 4 } & 500 & 3.2 & 2.6 \\
\cline { 2 - 4 } & 200 & 3.8 & 2.2 \\
\cline { 2 - 4 } & 100 & 4.2 & 2 \\
\cline { 2 - 4 } & 50 & 6.2 & 1.6 \\
\hline \multirow{4}{*}{ 6b } & 3000 & 1 & 8.5 \\
\cline { 2 - 4 } & 1000 & 1.5 & 5.3 \\
\cline { 2 - 4 } & 500 & 2.5 & 3.4 \\
\cline { 2 - 4 } & 200 & 3.9 & 2.1 \\
\cline { 2 - 4 } & 100 & 4.3 & 1.9 \\
\cline { 2 - 4 } & 50 & 6.8 & 1.25 \\
\hline \multirow{4}{*}{$6 \mathrm{c}$} & 3000 & 1.5 & 5.3 \\
\cline { 2 - 4 } & 1000 & 2.3 & 3.6 \\
\cline { 2 - 4 } & 500 & 3.1 & 2.6 \\
\cline { 2 - 4 } & 200 & 3.5 & 2.4 \\
\cline { 2 - 4 } & 100 & 4.2 & 1.8 \\
\cline { 2 - 4 } & 50 & 5.9 & 1.4 \\
\hline
\end{tabular}

${ }^{\mathbf{a}}(\mu \mathrm{g} / \mathrm{ml})-^{\mathbf{b}}$ Expressed by $\log _{10} \mathrm{TCID}_{50}{ }^{-}{ }^{\mathbf{c}}$ The reduction $(n$ fold) was calculated by dividing the virus titer into untreated cells by the virus titer in treated cells. ${ }^{\mathbf{d}}$ Results are means from three repetitions.

Therapeutic index (TI) of amantadine $=$ BHK Cytotoxic concentration fifty $\left(\mathrm{CC}_{50}\right) /$ BHK inhibitory concentration fifty $\left(\mathrm{EC}_{50}\right)=3000 / 100=30$

Results of Table 4 showed that, $50 \mu \mathrm{g} / \mathrm{ml}$ of pyrazoles $6 \mathrm{a}$ and $6 \mathrm{c}$ achieve $100 \%$ survival among baby mice while bis-tolyl pyrazole derivatives $6 \mathrm{~b}$ gives $\% 100$ survival at $40 \mu \mathrm{g} / \mathrm{ml}$ compared with amantadine which gives $\% 100$ survivals at $50 \mu \mathrm{g} / \mathrm{ml}$ as shown in Table 4 and Fig. 2.

Table 4: Antiviral activity of adamantane pyrazole derivatives in Baby mice

\begin{tabular}{|c|c|c|c|}
\hline $\begin{array}{c}\text { Name of } \\
\text { compounds }\end{array}$ & Concentrations & $\begin{array}{c}\text { Total } \\
\text { number } \\
\text { of baby } \\
\text { mice }\end{array}$ & $\begin{array}{c}\% \\
\text { percentage } \\
\text { of survival }\end{array}$ \\
\hline \multirow{5}{*}{$6 a$} & 100 & 10 & $100 \%$ \\
\hline & 50 & 10 & $100 \%$ \\
\hline & 40 & 10 & $50 \%$ \\
\hline & 30 & 10 & $0 \%$ \\
\hline & 20 & 10 & $0 \%$ \\
\hline \multirow{5}{*}{$6 b$} & 100 & 10 & $100 \%$ \\
\hline & 50 & 10 & $100 \%$ \\
\hline & 40 & 10 & $100 \%$ \\
\hline & 30 & 10 & $50 \%$ \\
\hline & 20 & 10 & $0 \%$ \\
\hline \multirow{5}{*}{$6 c$} & 100 & 10 & $100 \%$ \\
\hline & 50 & 10 & $100 \%$ \\
\hline & 40 & 10 & $50 \%$ \\
\hline & 30 & 10 & $0 \%$ \\
\hline & 20 & 10 & $0 \%$ \\
\hline Amantadine & 50 & 10 & $100 \%$ \\
\hline$*+$ ve control & - & 10 & $0 \%$ \\
\hline
\end{tabular}

Generally, the most promising three derivatives 6a-c exhibited binding energy (S) from -15.41 to -20.0 $\mathrm{kcal} / \mathrm{mol}$ in comparison to Amantadine $(\mathrm{S})=-6.15$ $\mathrm{kcal} / \mathrm{mol}$, and Ribavirin $(\mathrm{S})=-10.77 \mathrm{kcal} / \mathrm{mol}$. The three pyrazole derivatives are only different in substituents in two aryl groups at positions three and five of the pyrazole core. Docking of Amantadine drug inside the active site displayed one hydrogen bond backbone donor with bond length $2.49{ }^{\circ} \mathrm{A}$ and $41 \%$ strength. At the same time, Ribavirin showed four sidechain hydrogen bond acceptor between Lys 51 and oxygen of carbonyl of the amide group, the nitrogen of triazole, oxygen of furan nucleus and hydroxy group of methanol derivative with bond length 3.19 (13\%), 2.63 (72\%), $3.18(27 \%)$ and $2.60^{\circ} \mathrm{A}(83 \%)$ respectively.

By using the docking simulation was carried out using MOE software (Molecular Operating Environment 10.2008 provided with chemical computing group, Canada.) with a standard protocol that previously reported (Salem et al.,2020), and the docking process was performed according to the reported methods (Fukuda, And Umeki, 2017).

Pyrazole derivatives 6a showed the highest binding energy $(\mathrm{S})=-20.00 \mathrm{kcal} / \mathrm{mol}$ with only one sidechain hydrogen bond acceptor between Lys 51 and oxygen of methanone amantadine derivatives with bond length $3.07^{\circ} \mathrm{A}$ and strength of the bond (32\%) as shown in Table 5. Also, compound 6a interacts through its pyrazole derivatives with three arene-cation interaction between Lys 51 and anisidine group at position five in pyrazole as well as Arg 68 that form two arene-cation with both pyrazole ring and phenyl group at position 3 as well as hydrophobic interaction that appear between active site in pocket and Amantadine part or phenyl group (appear as blue color on the chemical structure in 2D) (Fig. 3).

The pyrazole derivatives with bis-tolyl groups in positions three and five were revealed hydrogen bond acceptor from sidechain between Arg 68 and oxygen of methanone derivative with bond length 2.87 ${ }^{\circ} \mathrm{A}$ and strength (14\%) (Fig. 4). In addition to one arene-cation interaction through the tolyl group at position five and Lys 51 and hydrophobic interaction that arises due to the presence of amantadine and $p$ tolyl moiety.

Furthermore, pyrazole derivatives $6 \mathrm{c}$ that containing phenyl and $p$-chlorophenyl as two aryl derivatives observed binding energy $S=-18.02$ $\mathrm{kcal} / \mathrm{mol}$ with sidechain hydrogen bond acceptor between Arg 68 and oxygen of carbonyl of the methanone derivative with bond length $2.51{ }^{\circ} \mathrm{A}$ and $(30 \%)$ strength. Besides two arene-cation interaction between Arg 68 with the $p$-chlorophenyl group and Lys 
51 with phenyl group at the position three and five in pyrazole core respectively, (Fig. 5).

Finally, the pyrazole derivatives hybrid with Amantadine core 6a-c suggested being $3 \mathrm{C}$ protease inhibitor and exhibited binding energy higher than the two standard drugs Amantadine $(S=6.15 \mathrm{kcal} / \mathrm{mol})$ and Ribavirin $(\mathrm{S}=10.77 \mathrm{kcal} / \mathrm{mol})$ with different binding mode. All the docked pyrazole derivatives 6a-c showed favorable binding interactions with hydrophobic interaction and energy scores from -15.41 to -20.0 $\mathrm{kcal} / \mathrm{mol}$ in comparison to Amantadine $(\mathrm{S})=-6.15$ $\mathrm{kcal} / \mathrm{mol}$, and Ribavirin $(\mathrm{S})=-10.77 \mathrm{kcal} / \mathrm{mol}$. These highest binding energy and binding interactions suggest that these compounds may act as $3 \mathrm{C}$ protease inhibitors and thus may participate as antiviral drugs.

Table 5: Docking results of the most promising pyrazole derivatives inside the active site (5MH2) as well as two reference drugs Amantadine and Ribavirin used in this study

\begin{tabular}{|c|c|c|c|c|c|}
\hline $\begin{array}{l}\text { Cpd. } \\
\text { No. }\end{array}$ & $\begin{array}{c}\text { Energy score } \\
\text { (S) } \\
(\mathrm{Kcal} / \mathrm{mol})\end{array}$ & $\begin{array}{l}\text { Amino } \\
\text { acids }\end{array}$ & Interacting groups & Length $(\AA)$ & $\begin{array}{c}\text { Strength } \\
(\%)\end{array}$ \\
\hline \multirow{4}{*}{$6 a$} & \multirow{4}{*}{-20.00} & Lys 51 & O- of the carbonyl group & 3.07 & 32 \\
\hline & & Lys 51 & Anisidine group & - & - \\
\hline & & $\operatorname{Arg} 68$ & Pyrazole moiety & - & - \\
\hline & & $\operatorname{Arg} 68$ & Phenyl group & - & - \\
\hline \multirow{2}{*}{$6 b$} & & Arg 68 & O- of the carbonyl group & 2.87 & 14 \\
\hline & -15.41 & Lys 51 & Tolyl group & - & - \\
\hline \multirow{3}{*}{$6 c$} & & Arg 68 & O- of the carbonyl group & 2.51 & 30 \\
\hline & & $\operatorname{Arg} 68$ & $p$-chlorophenyl & - & - \\
\hline & -18.02 & Lys 51 & phenyl group & - & - \\
\hline Amantidine $\mathrm{HCl}$ & -6.15 & Val 69 & Amino group of amantadine & 2.49 & 41 \\
\hline \multirow{5}{*}{ Ribavirin } & \multirow{5}{*}{-10.77} & Lys 51 & Carbonyl of the amide group & 3.19 & 13 \\
\hline & & Lys 51 & Nitrogen of triazole & 2.63 & 72 \\
\hline & & Lys 51 & The Oxygen of furan derivatives & 3.18 & 27 \\
\hline & & Lys 51 & Hydroxy of methanol derivative & 2.60 & 83 \\
\hline & & Val 69 & $\begin{array}{l}\text { Hydroxy of furan derivative in } \\
\text { position } 4\end{array}$ & 2.77 & 81 \\
\hline
\end{tabular}
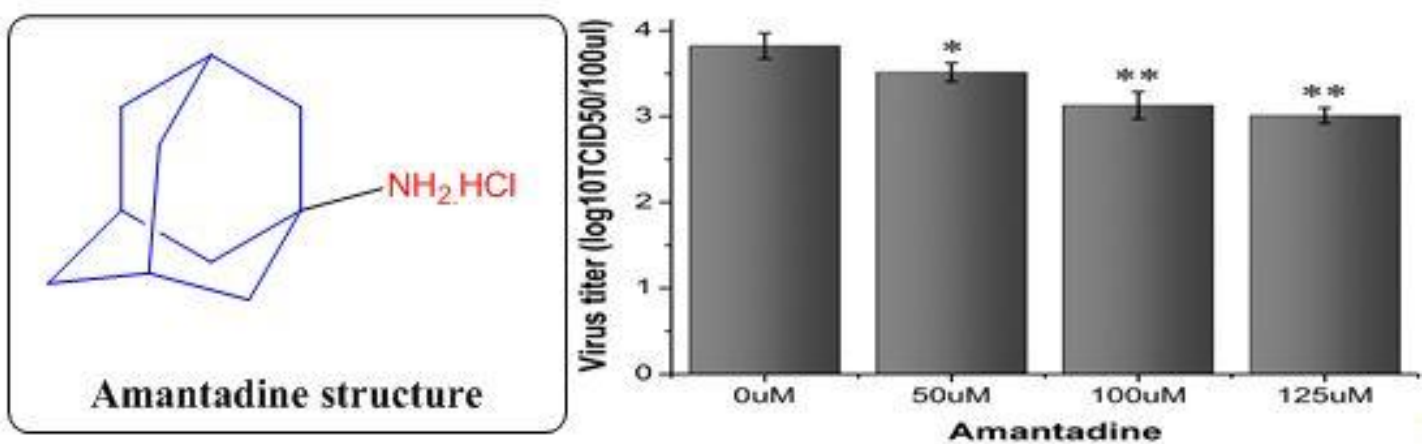

Fig.1: Structural and the effect of amantadine on the release of FMDV virions. BHK-21 cell cultures were infected with FMDV (MOI/0.1) and then treated with amantadine (AO et al. , 2015). 
Mohammed M. S. Wassel et al.....

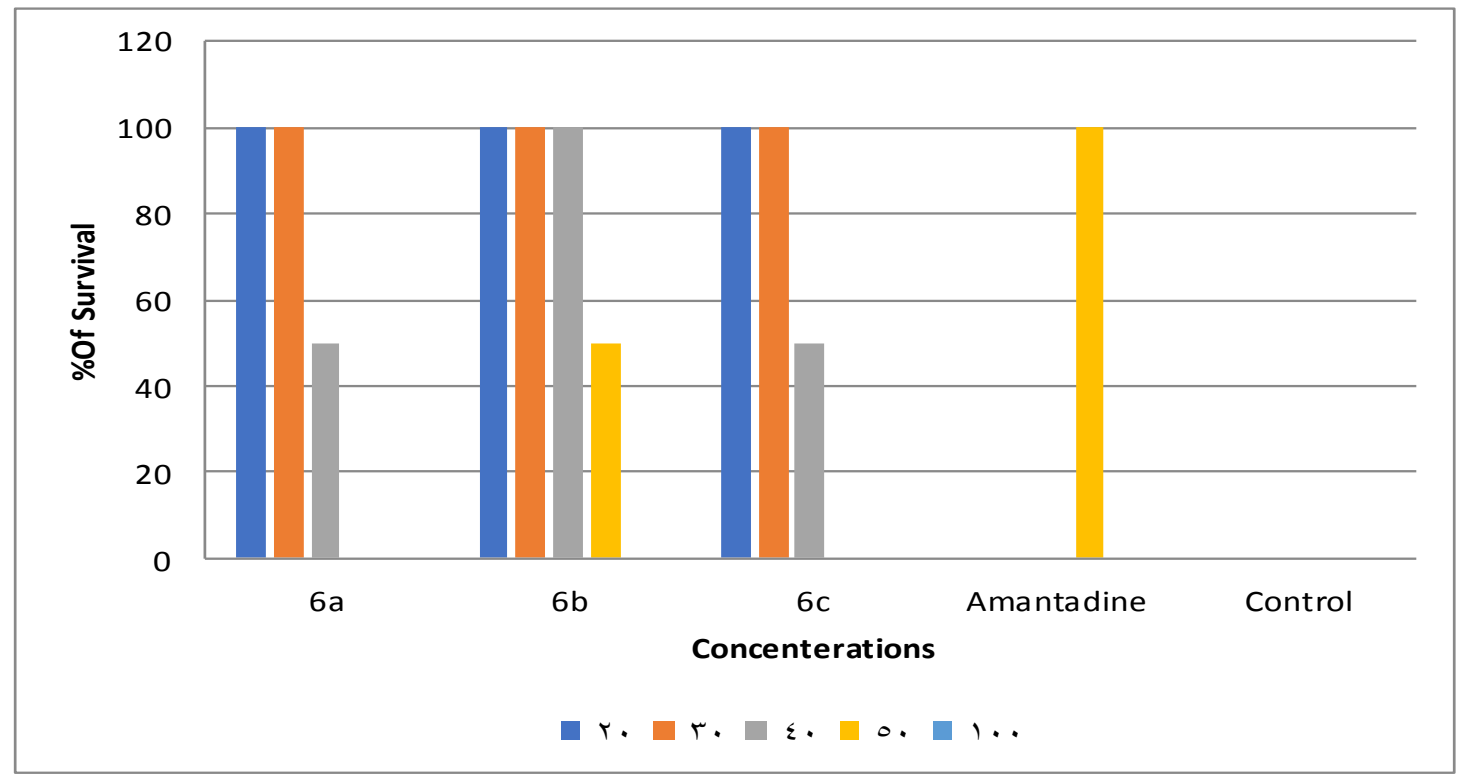

Fig.2: Antiviral activity of adamantane pyrazole derivatives (6a, $6 \mathrm{~b}$ and $6 \mathrm{c})$ in Baby mice
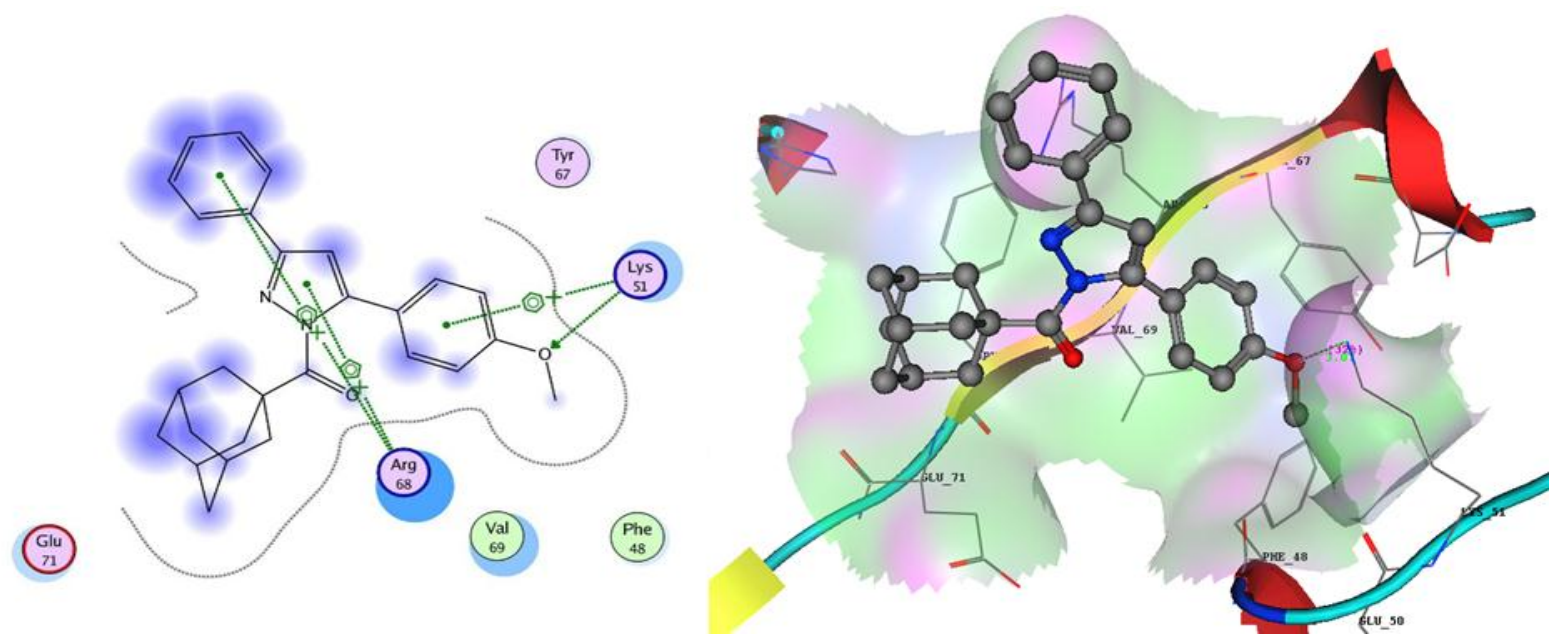

Fig. 3: 2D \& 3D interactions of pyrazole derivative $6 \mathrm{a}$ in the active site of $5 \mathrm{MH} 2$
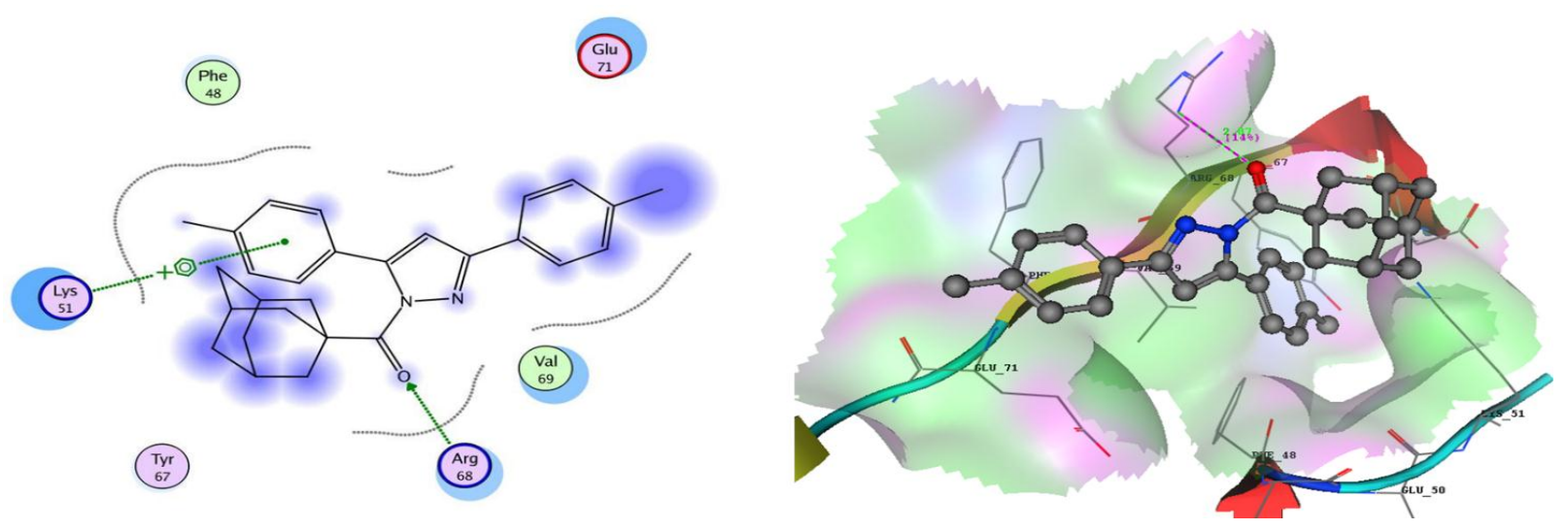

Fig. 4: $2 \mathrm{D} \& 3 \mathrm{D}$ interactions of pyrazole derivative $6 \mathrm{~b}$ in the active site of $5 \mathrm{MH} 2$ 

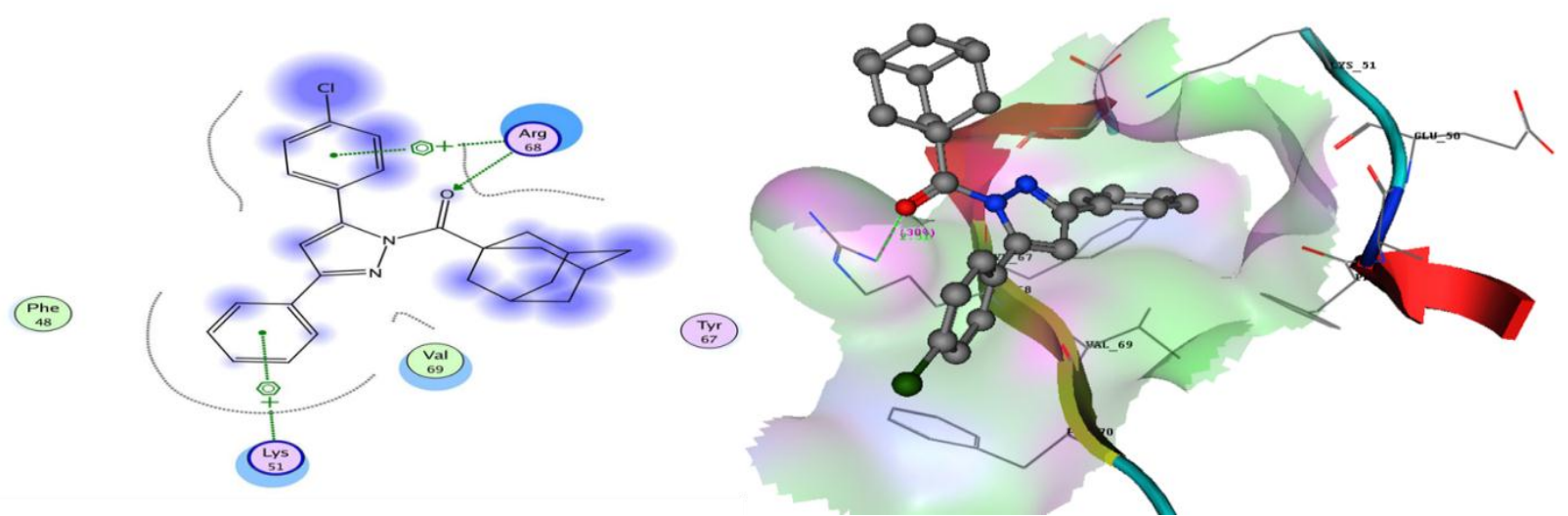

Fig.5: 2D \& 3D interactions of pyrazole derivative $6 \mathrm{c}$ in the active site of $5 \mathrm{MH} 2$

\section{DISCUSSION}

In enzootic countries like Egypt, vaccination of susceptible livestock is the method of choice to build herd immunity and ultimate control and eradication of FMD. However, the conventional FMD vaccine induces complete protection after seven days postvaccination. Following the acute FMDV infection in ruminants, some proportions of them become carriers to FMDV (Diaz-San.,2017). To overcome these issues, emergency immunization with a high potency vaccine is practiced. The other possible alternatives would be the use of antiviral agents that inhibit FMDV replication.

Adamantane derivatives are known to have a broad spectrum of biological activity including antiviral effects. Adamantane derivatives that are entrenched well into medical practice include drugs such as amantadine, rimantadine, tromantadine, ladasten, and many others. Compounds with antitumor (Long. et al., 2007) and antimalarial (Singh et al., 2007) activity; for application as antidiabetic (Villhauer et al.,2003) and antituberculosis (Nayyar et al., 2007) agents, CB1 receptor agonists (Lu et al.,2005 and Stem et al., 2007) and neuroprotective compounds (Jensen et al., 2006 and Schlesinger et al., 2005). Furthermore, for treatment of Gaucher's disease (Yu et al., 2007) and therapy of viral infections (Motornaya et al., 2006 and Boreko et al., 2007) are now undergoing pharmacological testing.

Therefore, the present study aimed to explore the in vitro antiviral efficacy of adamantane-pyrazole derivatives by their inhibition of CPE in BHK-21 cell culture system against FMD virus serotype $(\mathrm{O})$ after checking their cytotoxic activity on BHK-21 and also evaluating the antiviral activity of selected compounds of supposed antiviral activity against FMDV in vivo through antiviral reagent injection, viral challenge, and monitoring in suckling baby mice.

Regarding the $\mathrm{CC}_{50}$ results for each compound, the tested concentration used was below the $\mathrm{CC}_{50}$ to study its inhibitory effect on FMDV replication. So, it was selected six concentrations from each compound (concentrations below $\mathrm{CC}_{50}$ ) to test antiviral activity by virus titration assay on BHK-21 cells which was expressed as $\log _{10} \mathrm{TCID}_{50}$ for $24 \mathrm{hrs}$. The Inhibitory concentration $50 \%\left(\mathrm{EC}_{50}\right)$ was detected for each compound and the fold reduction was calculated according to (Mauro et al., 2007) through dividing the virus titer into untreated cells by the virus titer in treated cells. The $\mathrm{CC}_{50}$ of compounds $6 \mathrm{a}, 6 \mathrm{~b}$ and $6 \mathrm{c}$ compounds come in parallel with that obtained for amantadine compound by (Aggour., 2006) who showed that the $\mathrm{CC}_{50}$ of amantadine was $3000 \mu \mathrm{g} / \mathrm{ml}$. As mentioned by (Sakar et al .2019) who stated that the differences in cytotoxic concentration 50 were attributed to intrinsic characteristics of the cell, factors related to the drug.

Concerning in vivo evaluation of the selected compounds was achieved through testing the antiviral activity against FMDV challenge in baby mice. Clinical signs observed in the treated and control mice: The control mice showed typical clinical signs such as spastic muscular paralysis of hindquarters leading to death. Combination of clinical treatment strategies has been proposed to increase the efficacy of antiviral agents, because of their advantages in overcoming viral mechanisms of resistance to antiviral actions (Kim and Park.,2012).

In agreement with diaryl pyrazole derivatives 6a-c, the therapeutic index (TI) which is defined as the relative effectiveness of the investigational product in inhibiting viral replication compared to inducing cell death (FDA., 2006) and according to (White and Fenner 1984) who reported that the effective antiviral was highest therapeutic index preferably more than 10 . This may be contributed to what stated by (Moiseev $\boldsymbol{e} t$ al., 2012) that the high lipophilicity and unique geometry of the adamantine skeleton enhances considerably the permeability and adsorption of this type of compounds to cell membranes. This is the reason for the manifestation of the virus-inhibiting action through suppression of the early stages of the virus reproductive cycle. Incorporation of an adamantine moiety into molecules of various 
biologically active compounds modifies their pharmacologic action significantly.

Amantadine is a real inhibitor of viroporins, including the IAV M2 protein (Intharathep and Pinto., 2008). The HCV 77 protein (Steinmann and Whitfield.,2007).and the C-terminal subunit of the p13 protein (p13-C) of GB virus B(GBV-B) (Premkumar and Dong., 2006). As previously established, viroporins can promote the release of virions. To investigate the possible mechanism of virion release, the effects of amantadine on FMDV replication were estimated (Gladue, and Holinka.,2012).

Modeling studies are of high importance to obtain a consistent, clearer picture of the biologically active molecules that could be used to design novel therapeutic agents ( El-Sharief, et al., 2020) and ( Hassan, et al., 2020). (Our work was extended to investigate the plausible binding pattern and interaction with the vital amino acids inside the active site with the most promising three derivatives 6a-c. Molecular docking simulation was performed inside the active site of the $3 \mathrm{C}$ protease, where the protein that was used for this purpose (PDB: 5MH2) was downloaded from protein data bank (https://www.rcsb.org).

\section{CONCLUSIONS}

The present study is the first to demonstrate that adamantane pyrazole derivatives can suppress FMDV replication in vitro as well as prolong the survival of mice in vivo, suggesting the potential applications of this drug as an antiviral regiment for FMD treatment. Finally, in recommendations: it is necessary to test the antiviral effect of pyrazole containing two arylidine groups at position three and five in natural hosts such as swine, cattle, and goats, and against more FMDV strains.

\section{Declaration of Competing interest}

On behalf of all authors, I hereby declare that no conflict of interest may interfere with the publication of the manuscript.

\section{REFERENCES}

AO. D., GUO. H-C., SUN. S-Q., SUN. D-H., FUNG. TS., WEI. Y-Q. 2015. Viroporin Activity of the Foot-andMouth Disease Virus Non-Structural 2B Protein. PLoSONE, 10(5): e0125828.

AGGOUR. A. MA. 2006. The effect of amantadine as antiviral on foot and mouth virus replication, Zag. Vet. J. vol.34, NO.2, page.103-108.

AGNEW-FRANCISA. K. A. AND WILLIAMS. C. M., SYNTH.CATAL. ADV. 2016. Catalysts Containing the Adamantane Scaffold, advanced synthesis and catalysis review, 358, 675-700.

AUGERI. D. J., ROBL. J. A., KIM. SM., PARK. J.H., LEE. KN., KIM.SK., YJ KO., LEE. IS. 2012. Enhanced inhibition of foot-and-mouth disease virus by combinations of porcine interferon-alpha and antiviral agents. Antivir. Res., 96, 213-220.

BOREKO. E. I., KLIMOCHKIN. YU. N., SHIRYAEV. A. K. 2007. Progress in Adamantane Chemistry [in Russian], Khimiya, Moscos, pp. 70-88.

DIAZ-SAN. SF., MEDINA. GN., STENFELDT. C., ET AL., 2017. Foot-and-mouth disease vaccines, Vet. Microbiol. 206,102-112.

EL-SHARIEF. AMS., AMMAR. Y. A., BELAL. A., ELSHARIEF. MAS., MOHAMED. Y. A., MEHANY. A.B. and RAGAB. A., 2019. Design, synthesis, molecular docking and biological activity evaluation of some novel indole derivatives as potent anticancer active agents and apoptosis inducers. Bioorganic Chemistry, 85, 399-412.

FUKUDA.T., UMEKI. T., TOKUSHIMA. K., XIANG. G., YOSHIDA. Y., ISHIBASHI, F., IWAO. M.,2017. Design, synthesis, and evaluation of A-ringmodified lamellar in $\mathrm{N}$ analogues as noncovalent inhibitors of the EGFR T790M/L858R mutant. Bioorganic \& medicinal chemistry,25(24), 6563-580.

FDA., 2006. Guidance for industry antiviral product development -conducting and submitting virology studies to the agency.

GRUBMAN. MJ and BAXT. B., 2004. Foot-and-mouth disease, Clinical Microbiology. Reveiw. 17, 465-493.

GLADUE. DP., HOLINKA. LG., LARGO. E., FERNANDEZ. S. I., CARRILLO. C., O'DONNELL. V., 2012. Classical swine fever virus p7 protein is a viroporin involved in virulence in swine. Journal of virology. 86(12):6778-91.

haSSAN. A. S., ASKar. A. A., NAGlah. A. M., ALMEHIZIA. A. A., AND A. RAGAB,2020. Discovery of New Schiff Bases Tethered Pyrazole Moiety: Design, Synthesis, Biological Evaluation, and Molecular Docking Study as Dual Targeting DHFR/DNA Gyrase Inhibitors with Immunomodulatory Activity. Molecules, 25(11), 2593.

IBRAHIM. E. E., EL-HELW. H.A., SHAFIK. N.G. AND MEKHAIL. M. A., 2017. Conjugation of Foot And Mouth Disease IgY In Chicken Egg Yolk With Horse Radish Peroxidase For Typing of Foot And Mouth Disease Virus. Journal of Applied Veterinary Sciences, 2(1): 35-42.

IGUMNOVA. N. D., LEMINA. E., BITIUKOVA. I. I., KLIMOVA. N. V. AND SKOLDINOV. A. P., FARMAKOL. T., 1988. Hydrolysis by plasma cholinesterase of complex adamantyl-containing esters. Farmakol Toksikol,51, 38-41.

INTHARATHEP. P., LAOHPONGSPAISAN. C., RUNGROTMONGKOL. T., LOISRUANGSIN. A., MALAISREE. M., DECHA. P., 2008. How amantadine and rimantadine inhibit proton transport in the M2 protein channel. Journal of molecular graphics \& modelling. 27(3):342-8.

JENSEN. L. S., BOLCHO. U., EGEBJERG. J.,2006. Drugs Targeting Protein-Protein Interactions .Chem. Med. Chem., 1(4), 419-428.

KAZIMIERCZUK. Z., GORSKA. A., SWITAJ. T., AND LASEK. W., 2001. Adamantyl amino pyrimidines and -pyridines are potent inducers of tumor necrosis factor-alpha. Bioorg. Med. Chem. Lett., 11, 11971200. 
KITAGAWA. K., MIZOBUCHI. N., HAMA. T., HIBI. T., KONISHI. R. AND FUTAKI. S.,1997. Synthesis and Antinociceptive Activity of [DAla ${ }^{2}$ Leu-Enkephalin Derivatives Conjugated with the Adamantane Moiety. Chem. Pharm. Bull., 45, 1782-1787.

LONG. J., MANCHANDIA. T., BAN. K., 2007. Adaphostin cytoxicity in glioblastoma cells is ROSdependent and is accompanied by up regulation of heme oxygenase-1.Cancer Chemother. Pharmacol, 59, 527-535.

LU. D., MENG. Z., THAKUR G. A., 2005. Adamantyl Cannabinoids: A Novel Class of Cannabinergic Ligands .J. Med. Chem., 48(14), 4576-4585.

MAURO. P., MORAES. K., TERESA. S., MARLA. D., TRACI. S., HE. W., VLADIMIR. G., AND MARVIN. J. G.,2007. Enhanced Antiviral Activity against Foot-and-Mouth Disease Virus by a Combination of Type I and II Porcine Interferons, J. of virology, p. 7124-7135.

MOTORNAYA. A. E., ALIMBAROVA. L. M., SHOKOVA. E. A., 2006. Synthesis and antiherpetic activity of N-(3-amino-1-adamantyl)calix[4]arenes. Pharm. Chem. J., 40(2), 68-72.

MORAES. MP, DE LOS. S.T., KOSTER. M., et al.,2007. Enhanced antiviral activity against foot and-mouth disease virus by a combination of type I and II porcine interferons, J. Virol., 81, 7124-7135.

MOREL-DESROSIERS. N., AND MOREL. J. P.,1979. Standard molar enthalpies, volumes, and heat capacities of adamantane in cyclohexane, $n$-hexane, and carbon tetrachloride. Interpretation using the scaled-particle theory .J. Solution Chem., 8, 579-592.

MOISEEV I. K., KON'KOV. S. A .,OVCHINNIKOV. K. A., 2012. Synthesis and antiviral activity of new adamantane derivatives.Pharmaceutical Chemistry Journal vol.45, pages588-592.

NAYYAR. A., MONGA. V., MALDE. A., 2007. $\underline{\text { Synthesis, }}$ anti-tuberculosis activity, and 3D-QSAR study of 4(adamantan-1-yl)-2-substituted quinolines .Bioorg. Med. Chem., 15(2), 626-640.

PINTO. LH., LAMB. RA.,2007. Controlling influenza virus replication by inhibiting its proton channel. Molecular bioSystems. 3(1):18-23.

PREMKUMAR. A., DONG. X., HAQSHENAS. G., GAGE. PW., GOWANS. EJ.,2006. Amantadine inhibits the function of an ion channel encoded by GB virus $B$, but fails to inhibit virus replication. Antiviral therapy.,11(3):289-95.

REED. LJ, MUENCH. H.,1938. A simple method for estimating fifty percentage end point. Am. J. Hyg., 27:493-497.

SALEM. M. A., RAGAB. A., EL-KHALAFAWY. A., MAKHLOUF. A. H., ASKAR. A. A. and AMMAR. Y. A., 2020. Design, synthesis, in vitro antimicrobial evaluation and molecular docking studies of indol-2-one tagged with morpholinosulfonyl moiety as DNA gyrase inhibitors. Bioorganic Chemistry, 96, 103619.

SCHLESINGER. F., TAMMENA. D., KRAMPFL. K., AND BUFLER. J., BR 2005. Two mechanisms of action of the adamantane derivative IEM-1460 at human AMPA-type glutamate receptors. J. Pharmacol., 145(5), 656-663.

SARKAR S., RAMASAMY. P. T. S., VEERAKYATHAPPA. B.,2019. In vitro antiviral efficacy of pleconaril and Ribavirin on foot-andmouth disease virus replication. Virus. Dis. 30(4):562-570.

SINGH.C., KANCHAN.R., SHARMA. U., AND S. PURI.K., 2007. New Adamantane-Based Spiro 1,2,4Trioxanes Orally Effective against Rodent and Simian Malaria. J. Med. Chem., 50(3), 521-527.

SOUDY. A.F., 2019. Prophylactic control of mycoplasma contamination in starting biological materials used in viral vaccine production, Journal of Applied Veterinary Sciences, 4(1): 30-34.

STEINMANN. E., WHITFIELD. T., KALLIS. S., DWEK. RA., ZITZMANN. N., PIETSCHMANN. T., 2007. Antiviral effects of amantadine and iminosugar derivatives against hepatitis $\mathrm{C}$ virus. Hepatology. 46(2):330-8.

STROBER. W., 2011. Trypan blue exclusion test of cell viability. Curr Protocol Immunol. 111:A3.B.1A3.B.3, 1-2.

VILLHAUER. E. B., BRINKMAN. J. A., NADERI. G. B., 2003. 1-[[(3-Hydroxy-1-damantyl)amino]acetyl]2-cyano-(S)-pyrrolidine: A Potent, Selective, and Orally Bioavailable Dipeptidyl Peptidase IV Inhibitor with Antihyperglycemic Properties.J. Med. Chem., 46(13), 2774-2789.

WASSEL. M.M.S., RAGAB. A., ELHAG ALI. G.A.M., MEHANY. A. B. M. and AMMAR. Y. A., ,2020. Novel adamantane-pyrazole and hydrazone hybridized: design, synthesis, cytotoxic evaluation, SAR study and molecular docking simulation as carbonic anhydrase inhibitors. Journal of Molecular Structure, 1223,128966.

WHITE. DO. AND FENNER. FJ., 1984. Antiviral chemotherapy, interferons and vaccines. ,Monographs in Virology.pp. 36-48.

XUAN. H., LI. Y., FANG. H., ANDZHENG. C., 2011. Establishement of persistent infection with foot and mouth disease virus in BHK-21cells.virol. J.,8:169.

YU. Z., SAWKAR. A. R., WHALEN. L. J., 2007. Isofagomine- and 2, 5-anhydro-2, 5-imino-D-glucitolbased glucocerebrosidase pharmacological chaperones for Gaucher disease intervention. J. Med. Chem., 50(1), 94-100.

ZHANG. Z. D., HUTCHING. G., KITCHING. P., AND ALEXANDERSEN. S., 2002. The effects of gamma interferon on replication of foot-and-mouth disease virus in persistently infected bovine cells. Arch. Virol. 147:2157-2167

How to cite this article:

Mohammed M. S. Wassel; Wael M. Gamal El-Din ; Ahmed Ragab; Gameel A. M. Elhag Ali and Yousry A. Ammar, (2020). Antiviral Activity Of AdamantanePyrazole Derivatives Against Foot And Mouth Disease Virus Infection In Vivo And In Vitro With Molecular Docking Study.Journal of Applied Veterinary Sciences, 5(4): 37 - 46.

https://dx.doi.org/10.21608/iavs.2020.118001 